\author{
ARTIGO

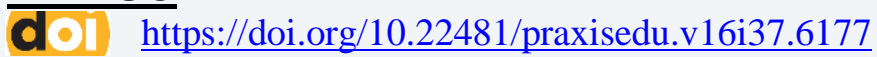

\title{
PEDAGOGICAL ASPECTS OF PRESCHOOL EDUCATION AND THE FORMATION OF EDUCATIONAL MOTIVATION IN CHILDREN
}

\author{
ASPECTOS PEDAGÓGICOS DE LA EDUCACIÓN PREESCOLAR Y LA FORMACIÓN \\ DE LA MOTIVACIÓN EDUCATIVA EN LOS NIÑOS
}

\begin{abstract}
ASPECTOS PEDAGÓGICOS DA EDUCAÇÃO PRÉ-ESCOLAR E A FORMAÇÃO DA MOTIVAÇÃO EDUCACIONAL EM CRIANÇAS
\end{abstract}

\author{
Aliyeva Shahla Gasim qizi \\ Azerbaijan State Pedagogical University - Azerbaijão
}

\begin{abstract}
The article has been devoted to the study of the directions for the development of motivation training at children in preschool education. Here we focus on different pressing problems of pre-school education, as well as the issues on motivation training for school of preschool children has been studied. The research showed that increasing the opportunities of motivation for school training of children has a great importance and this criterion is dominant in the development of cognitive demands and creation of training motives in the child's adaptation to school. It is found that the main motivation directions at pre-school training of children was directly conditioned bya game of the that was a leading activity. Improving the game activity, as well as its transformation to the cognitive motives not only increases the cognitive opportunities of child, but also directs his development as a personality, the cognitive opportunities of "May- conception". The study has shown that there is an important dependence between the motivation training and making true mutual relationships with the communation tips of the adults and children.
\end{abstract}

Keywords: pre-school education, motivation training in children, directions of development, preparation for school training.

Resumen: El artículo se ha dedicado al estudio de las instrucciones para el desarrollo de la capacitación motivacional en niños en educación preescolar. Aquí nos enfocamos en diferentes problemas apremiantes de la educación preescolar, así como también se han estudiado los temas de capacitación motivacional para niños en edad preescolar. La investigación mostró que aumentar las oportunidades de motivación para la formación escolar de los niños tiene una gran importancia y este criterio es dominante en el desarrollo de las demandas cognitivas y la creación de motivos de formación en la adaptación del niño a la escuela. Se descubrió que las principales instrucciones de motivación en la formación preescolar de los niños estaban directamente condicionadas por un juego que era una actividad líder. Mejorar la actividad del juego, así como su transformación a los motivos cognitivos, no solo aumenta las oportunidades cognitivas del niño, sino que también dirige su desarrollo como personalidad, las oportunidades cognitivas de la "concepción de mayo". El estudio ha demostrado que existe una importante dependencia entre el entrenamiento de la motivación y hacer verdaderas relaciones mutuas con los consejos de comunicación de adultos y niños. 
Palabras clave: educación preescolar, capacitación motivacional en niños, direcciones de desarrollo, preparación para la capacitación escolar.

Resumo: O artigo foi dedicado ao estudo das orientações para o desenvolvimento do treinamento motivacional em crianças na educação pré-escolar. Aqui, nos concentramos em diferentes problemas prementes da educação pré-escolar, bem como as questões sobre treinamento de motivação para crianças em idade pré-escolar foram estudadas. A pesquisa mostrou que aumentar as oportunidades de motivação para o treinamento escolar de crianças tem uma grande importância e esse critério é dominante no desenvolvimento de demandas cognitivas e na criação de motivos de treinamento na adaptação da criança à escola. Verifica-se que as principais orientações de motivação no treinamento pré-escolar das crianças foram diretamente condicionadas por um jogo do que era uma atividade de liderança. Melhorar a atividade do jogo, bem como sua transformação nos motivos cognitivos, não apenas aumenta as oportunidades cognitivas da criança, mas também direciona seu desenvolvimento como personalidade, as oportunidades cognitivas da "concepção de maio". O estudo mostrou que existe uma dependência importante entre o treinamento motivacional e o estabelecimento de verdadeiras relações mútuas com as dicas de comunhão de adultos e crianças.

Palavras-chave: educação pré-escolar, treinamento de motivação em crianças, direções de desenvolvimento, preparação para o treinamento escolar.

\section{Introduction}

The education system of the modern world should continue its efforts to create a modern education system in the direction of the world standards.In our country reform measures are being implemented at all levels of educationChanges in the socio-economic sphere in our country have led to serious changes in the education system as a whole and in its pre-school stage. The education system of the modern world should continue its efforts to create a modern education system in line with the world standards. Reform measures are being implemented at all levels of education in our country. Changes in the socio-economic sphere in the country have led to serious changes in the education system as a whole and in its pre-school stage.

Now, at the beginning of the third millennium, in the conditions of the transformation of Azerbaijani society, significant changes in all its fields, on the one hand, and scientific and technological progress, changes in the nature and content of labor, on the other, are required new approaches and solutions to develop an optimal strategy for the development of society. Is required critical analysis of available and possible options for socio-economic and political behavior, relevant scientific developments, recommendations and forecasts of social development, which can only be done creatively, a bold and free-thinking person highly cultured and deep constantly updated and developing knowledge. 
In modern conditions production, mode of life, forms of interaction between people demand from a person, a child, not only general education, and, first of all, discovery of individual abilities, allowing to achieve high results in work and make life more diverse.

Thus, today is actual society's need for individuals which could actively and constructively resolve the contradictions of socio-economic, political and cultural development, demonstrate creativity, initiativity.

The development of such an individual in our opinion can be carried out only on condition mastering by man of those values, norms and rules, on the basis of which any positive transformative activity can be carried out.

Consequently, meeting the needs of society in an active, creative, proactive subject of activity possible through the initiation of individuals not only to universal rules, norms, principles, values, but also their motivation for independent work to identify their inclinations, formation as subjects of activity. However, the education and upbringing system of the younger generation, which has existed for many years, today does not meet modern requirements, does not meet the actual needs of society.

So, we can fix the crisis of the system of education, the formation of consciousness and behavior of children, based on the development of social experience of previous generations and its transmission to future generations.

The traditional understanding of the essence of the educational process led and leads to the perception of the educated only as an object of affection.

A similar state is also characteristic of the education system. Based on the principles of optimization, unification of the educational process with its typification and standardization of curricula, programs and popularity of training, it does not and cannot lead society to the formation of a free, conscious, creative and self-developing personality.

Moreover, in conditions when modern Azerbaijan society is characterized by instability, imbalance, the system of upbringing and education of the younger generation does not fully ensure the effective adaptation of children to society, their inclusion in public life. In our opinion, in these conditions becomes relevant the issue of creating a new system of upbringing and education, which is not limited only to the transmission, translation of norms, values, knowledge and social experience, but becoming a consciously controlled process, based on special knowledge, as well as determining the basic principles of its construction. The crisis of the old education system is also the crisis of family accomplishment. If today we are talking 
about the scientific foundations of the new training system, it is logical to pose questions: can parents act as the leading institution for the upbringing of preschool children?

Can a family provide an active, creative, adaptive personality?How will originate the process of "adaptation" of the parents themselves to the new conditions, the requirements of life?

Under these conditions, upbringing as a process consciously controlled and based on special knowledge most realistically can be embodied in the sphere of preschool education.

And, consequently, it is actual to determine the quality, content and orientations of preschool education and upbringing in our country. I would like to note that currently there is a controversial perception by adults of the world of childhood and children. Today it is practically impossible to get a reasonable answer to the question of what a child is, what is his mission, the essence of development, who should he become and which should he become? Moreover, we can note that, despite the presence of sufficiently deep ideas about many aspects of human nature in such areas of scientific knowledge as philosophy, psychology, sociology, pedagogy, these sciences do not possess the required knowledge about the consistent patterns of human development both in ontogenesis and in preschool childhood.

And this, in turn, leads to an increase in the importance of the problem of analyzing the specifics of development of children in preschool age, identifying the consistent patterns of this process. The existence of different views on the specifics of the development of preschool children, in our opinion, leads to a lack of a univocal understanding of the purpose of functioning of the preschool stage of the education system. Even within the framework of sociological science today there are several points of view on the essence and content of its activities: as a stage in preparing children for school; as a stage in the development of a child's personality; as a period of formation in a child of the basic mechanisms and methods of effective adaptation to society. Consequently, the problem of identifying the essential characteristics, the meaningfulness of preschool education becomes significant.

An analysis of changes in the education system in Azerbaijan allows us to conclude that most modern pioneer works, innovations primarily touch upon to the reform of its school level. Changes in the field of preschool education, in our opinion, are mainly of a status, organizational, and not substantive nature.

This conclusion direct confirms the creation of numerous centers, gymnasiums and other institutions, as well as the increasing number of forms of organization of children's life, the main task of which is to more effectively prepare the child for school, which leads to the 
transition of preschool educational institutions to the status of a tutorial link between preschool and school periods of a child's life.

Consequently, it is relevant to analyze the current state of preschool education as a starting point for the implementation of innovations in this area, as well as determine the most promising directions for its reform.

The questions and problems posed by us in the field of preschool education require a qualified and justified answer, the receipt of which is possible only on the basis of a sociological study of the opinions, orientations and attitudes of modern parents, teachers and heads of preschool educational institutions, teachers.

Thus, the profession of a teacher of preschool children is gradually moving into the category characterized by the highest level of mobility.

In addition, it is becoming increasingly complex, which assumes the emergence of new tasks, behavioral paradigms and attitudes. Therefore, the system of advanced training of educators should be professional, i.e. constitute a communicative combined system of accumulation of academic and practical experience, which begins with teacher education and continues throughout the pedagogical career. A modern educator should be capable of mastering of new functions which demanded by the socio-economic trends of preschool education.

Modern education is at a new stage of his development - it is being modernized. This is facilitated by both social and economic changes in society. Today, at the stage of serious changes, Azerbaijani society especially needs competent, physically, morally and spiritually developed citizens. Preschool education is the first stage of a unified educational system, and plays a special role in the intellectual, physical and psychological development of children, shaping their personality and preparing them for school. The purpose of preschool education is to provide the normal future development establishing and forming the initial knowledge, abilities and habits on the basis of pedagogical laws the physical, mental, spiritual development from early ages of children. The preschool education is studied in family and preschool education institutions.

The role of preschool education in the development and upbringing of the growing up generation is great. It is the preschool institution gives the start to the development of the child's personality, and the success of his future life largely depends exactly on how the child develops in childhood. 
There are many pressing problems of preschool education for modern world. Among these problems, enhancing the motivation opportunities at children, as well as their psychological preparation for school program are the main problems of time. Providing the motivation opportunities of psycho-pedagogical preparation of children for school programs, being the main composition of education reforms is one of the main directions and goals of preschool education. It should be considered that the implementation of this task enhance the adaptation of children for school training and changes their attitude the training.

In conditions of modernization of education, the problem of children's readiness for schooling, one of the components of which is motivational readiness, continues to be actual. Despite the abundance of scientific works and practical programs on this problem, there is a lack of materials devoted to the study of the motivational sphere of preschool children and the formation of motivational readiness for schooling. Very often, parents are faced with a contradiction: they organize targeted preparation of the child for school, strive to teach them writing, reading, and counting before school, but as a result, the child shows a persistent unwillingness to go to school to study. That is, if the child does not have motivational readiness for school, then even with the necessary knowledge and skills, a high level of intellectual development, it will be difficult for him at school. It follows that motivational readiness is an integral part of the general psychological readiness for school, and this must be taken into account when preparing senior preschool children for systematic schooling.

\section{Method \\ Research Model}

The aim of our research was to study the relationship between the content of communication of a senior preschool child with close adults with components of the structure of motivational readiness. To diagnose motivational readiness for schooling, the following methods were used: the methodology "Conversation about the attitude to school and learning" and the methodology "Studies of the motivation for learning in older preschoolers". As a result of the diagnosis, it was revealed that both children and adults in the studied families put forward such a sphere of communication as household (10 out of 10 proposed situations are selected). The study selected 90 children from each preschool age group (4.5, 6 year olds). 


\section{Results and Discussions}

The modern level of development of science imposes immeasurably increased demands on the human mental activity. The main goal of education is to prepare a competitive younger generation. Therefore, educational institutions are called upon to form theoretical thinking among pupils, starting from childhood age. The organization of the assimilation of knowledge on the principle of theoretical generalization leads to the appearance of such neoplasms as the assimilation of universal laws by children, the separation the method of their activity from a whole, the establishment of generalized relations. Managing the process of assimilation the knowledge of pupils involves an impact on the learning process itself and should not be aimed at forcing children to perform the actions of the teacher, but rather to arouse the child's need for such control affection and the desire to fulfill them. For this, upbringing, development and training should be based on the internal forces of children, which, in our opinion, is the motivational sphere.

Motivational readiness for schooling is associated with the "internal position of the pupil" as a system of motives and needs of the child, manifested in a positive attitude to whole school - educational activity, especially to its aspects, directly related to learning (Gonina O.O., 2014). The completeness of the formation of a child's motivational readiness for school depends on many factors, among which family education and communication with close adults are of great importance. The family is the first social institution in which the child is included in the process of socialization. Family education from an early age directs the consciousness, volition, feelings of the child. In communication with parents, children acquire their first life experience, elementary knowledge and ideas about the environment, attitude to various aspects of reality, including schooling. The development of educational motivation in a child is often accompanied by typical mistakes made by adults (Gonina O.O., 2014).

The first of them is that parents do not support the child's desire to learn new things, without attaching serious significance to this. The second is that the task of creating motivation is shifted to kindergarten and school. Often these errors are combined.

In this connection, the study of the influence of family communication on the motivational readiness of children for school seems extremely actual, so that this will allow to determine directions for optimizing the psychological preparation of preschoolers for schooling using new forms of psycho-pedagogical work with parents. 
A.V.Zaporozhets (2011) was one of the first to experimentally study the problem of psychological readiness, highlighting the levels of psychological readiness for school as a general and special readiness. The author formulated his understanding of psychological readiness of child to school as: "an integral system of properties and qualities characterizing the child's achievement of a new higher stage of general physical, mental, moral and aesthetic development" [A.V.Zaporozhets, 2011]

In the works of L.I.Bozhovic [2012] notes that "the success of schooling requires the formation of such sides of the psyche that are expressed in the child's specific attitude to school, teacher, and learning." Among the components of psychological readiness, the author calls a certain level of motivational development, including cognitive and social motives, the development of arbitrariness and intellectual sphere . [ Bozhovic L.I. 2012]

In the works of D.B.Elkonin [2012] children's psychological readiness for school is entirely determined by the presence of prerequisites and sources of educational activities. The main ones are: ability of the child to be guided by the system of rules in work, the ability to listen and follow the instructions of adults, the ability to work according to the model [Elkonin D.B. 2011].

Indicators of psychological readiness for school in several researches "the child's ability to consciously subordinate their actions to a given rule with the consistent implementation of adult verbal instructions". [Tsekhanskaya L.I., 2013]

The components of a child's psychological readiness for schooling are: motivational, intellectual, emotional-volitional readiness, readiness for sphere of communication.

Researchers highlight a very important point in the development of psychological readiness for a senior preschooler's school is the degree of development of the motivationalneed sphere, which is caused by the formation of learning motives and the development of cognitive interests throughout the preschool age [Elkonin, D.B., 2011, Tuguleva G.V. 2015, A. Alizade 1999].

Researchers highlight a very important point in the development of psychological readiness for a senior preschooler's school is the degree of development of the motivationalneed sphere, which is caused by the formation of learning motives and the development of cognitive interests throughout the preschool age [Elkonin D.B., 2011, Tuguleva G.V. 2015, A. Alizade 1999].

Thus, the psychological readiness of older preschool children for schooling, first of all, is appeared in the formation of motivation for preschool activity among preschoolers, 
allowing him to effectively engage in the learning process. At the same time, the motivational readiness of a preschooler cannot be formed without the necessary and sufficient level of development of the intellectual and arbitrary sphere of the future first-grader.Motivational readiness for schooling is a positive attitude to school, to learning as a serious, complex, but necessary activity [Tuguleva G.V. 2015]. Indicators of motivational readiness: desire to go to school; correct ideas about the school; cognitive activity.

The following conditions will contribute to the most effective formation of motivational readiness in children of preschool age: the development of interest in the role of the pupil, school attributes: form, is not enough. In this area, school supplies; the awakening of curiosity as a means of stimulating cognitive interest in new knowledge and buying or selling financial skills; systematic interaction of preschool and parents.

The theory and practice of preschool education shows that the period of preschool childhood is the most favorable for the formation of the necessary mental functions [A. Alizade 1999]

Thus, the pedagogical readiness of older preschool children for schooling, first of all, is manifested in the formation of motivation for preschool children in learning activities, allowing him to effectively engage in the learning process. At the same time, the motivational readiness of a preschooler cannot be formed without the necessary and sufficient level of development of the intellectual and arbitrary sphere of the future first-grader.

Motivational readiness for schooling is a positive attitude to school, to learning as a serious, complex, but necessary activity [Tuguleva G.V. 2015]. Indicators of motivational readiness: desire to go to school; correct ideas about the school; cognitive activity.

The following conditions will contribute to the most effective formation of motivational readiness in children of preschool age: development of interest in the role of the student, school attributes: form, not enough school supplies in this area; the awakening of curiosity as a means of stimulating cognitive interest in new knowledge and buying or selling financial skills; systematic interaction of preschool and parents.

The theory and practice of preschool education shows that the period of preschool childhood is the most favorable for the formation of the necessary mental functions [A. Alizade 1999].

It was at this time that the psycho-pedagogical prerequisites for future educational activities at school were laid, adaptation to new conditions and entry into a new system of relations. The effectiveness of the formation of motivational readiness for learning at 
preschoolers can be judged by the following criteria: children show interest in doing developmental tasks, in special exercises aimed at developing cognitive activity; children show a great desire to cooperate with the teacher at conducting joint adult and child affairs, during educational activities.

In general meaning of motivational readiness formation is that it is desireble for the teacher to transfer preschool children from the levels of negative and indifferent attitude to learning to mature forms of a positive attitude to learning - effective, conscious and responsible.

\section{Discussion and Conclusion}

Initially, we tried to determine the directions of attitude of children for school training. The main goal has been separate the motives welded from the attitude and to identify the motivation opportunities at different preschool agechildren.

The study has shown that the attitude of 4-year-old preschool children towards the training and school is more positive unlike the other age groups. The shades of the attitude to school of 30 children which included to the experiment carrier a positive character in $75 \%$ comments. In the result of the conversations with them, it is identified that training motivation didn't dominantin these children. They view the school as a more creative place for games activity and its natural cause the main activity role of children in that age is the games that, the description of other situations out of this type of activity it is difficult for them. But this fact show that by organizing the game activity it could be formed the motivation to school training.

Table 1. The indicators (with \%) of the attitude to the training of the different preschool aged children

\begin{tabular}{|l|l|l|l|}
\hline Motives & $\begin{array}{l}\text { 4-year- } \\
\text { old } \\
\text { children }\end{array}$ & -year-old-children & $\begin{array}{l}\text { 6-year-old } \\
\text { children }\end{array}$ \\
\hline Positive attitude to school & 75.00 & 68.00 & 65.00 \\
\hline Negative attitude to school & 25.00 & 32.00 & 35.00 \\
\hline Total & 100.00 & 100.00 & 100.00 \\
\hline
\end{tabular}


As can be seen from Table 1, the attitude of 5-year-old preschool children to school is less positive unlike the 4-year-old groups, with $68 \%$. The shades of the attitude to school carries a positive character in $68 \%$ comments of the 30 children who involved to the experiment. On the basis of conversations, it is determined that the training motivation in those children dominates. It creates a condition to form the training motivation at children and understanding the impressions on school, writing-reading comprehension.

Therefore, the conversations and interviews with the 6-year old showed that the positive motives have fallen in percent in the attitude children to the training and school unlike the other age groups. Although all the components of preschool preparation at 6 year-old children, the main component, the indicators of the motivation components are low. This conditions from the attitudes of children to school activity as a social situation.

Table 2. The directions(with \%) of the motivationat preschool aged children.

\begin{tabular}{|l|l|l|l|}
\hline Attitude indicators & $\begin{array}{l}\text { Positive } \\
\text { attitude to } \\
\text { school }\end{array}$ & $\begin{array}{l}\text { Negative attitude to } \\
\text { school }\end{array}$ & $\begin{array}{l}\text { Neutrality } \\
\text { school attitude }\end{array}$ \\
\hline Motives & 65.00 & 82.00 & 41.00 \\
\hline Cognitive motives & 25.00 & 12.00 & 35.00 \\
\hline Social motives & 20.00 & 6.00 & 24.00 \\
\hline Total & 100.00 & 100.00 & 100.00 \\
\hline
\end{tabular}

As a result of the diagnosis, it was found that $40 \%$ of older preschool children, having a positive general attitude towards entering the school, recognizing the authority of the teacher, are guided not by the true motives of learning and cognition, but they choose the external attributes of school life as the dominant motives, and also have game motivation when do exercise to identify cognitive activity, and when choosing types of schools they are also guided by typical preschool activities - physical education-artistic content. The remaining $60 \%$ of children have a pronounced cognitive interest, but do not always understand the pithy side of school life. 
Table 3. The direction (with \%) of the motivation during the communication between adults and children of preschool age.

\begin{tabular}{|l|l|l|l|l|}
\hline Scale and spheres & Mother & Father & Grandparents & Tutor \\
\hline 1.Vital demands & ++ & + & ++++ & - \\
\hline $\begin{array}{l}\text { 2.Situative-household } \\
\text { actions }\end{array}$ & + & + & ++ & ++ \\
\hline 3.Joint formal trainings & ++ & + & + & ++++ \\
\hline 4.Cognitive motives & + & ++ & + & ++++ \\
\hline 5.Cognitive process & ++ & ++ & + & + \\
\hline 6. Realities of formal school. & + & + & + & ++ \\
\hline 7.Social interaction effects & ++ & ++ & ++ & ++++ \\
\hline $\begin{array}{l}\text { 8. The world of child's } \\
\text { thoughts }\end{array}$ & +++ & + & +++ & + \\
\hline 9.Emotions of a child & ++ & + & + & \\
\hline 10. "I "conception of a child & ++ & ++ & +++ & + \\
\hline
\end{tabular}

Note: + number indicates the advantage of the child's motivation, - number indicates the absence of child's motivation.

As can be seen from Table 3, those motives are developing more in communication of children and adults, they related to the game actions or vital relationships. This means that motivation opportunities in preschool children are linked to the social situation and conditioned by leading activities.

The study has shown that the communication of preschool children is free from situationality, and beginning to gain cognitive content. Cognitive motives in children 4-5 years of age are enhanced by cognitive motivation, the sense of urgency in the definition of adults, and personal communication motives are established. Verbal opportunities extend in children's communication, the development of the speech which is the main motives of it and word growth starts to enhance quickly. The communication of 3-4 year old children was established in the background of practical-emotional mutual relationships, in 4-6 year old children the demand to situational-business cooperation with their peers has strengthened. The content of the communication depends on the nature of playing activity of children. The content of the communication depends on the nature of the child's playing activities, while also increasing the sense of need for peer and the motives to recognize him is enhanced. 
It can be stated that children with a motivational focus on preschool activities and external school attributes have the game motive as main. They have reduced cognitive activity, they are distracted by extraneous stimulus when presenting text that carries new information. Thus, the results of the diagnostics of motivational readiness for learning showed that in preschool children with different types of attitudes toward school dominate various types of motives in the structure of motivational readiness for schooling. Preschoolers who have a high level of motivational readiness have a positive attitude towards entering and staying at school, expressed cognitive interest, prefer collective class lessons to an individo-domestic form of education, who prefer the school in which compliance with the rules of school discipline is mandatory, acception the mark as a form of educational assessment work to other types of encourage - sweets, toys, recognize the authority of the teacher. Children with medium and low motivation for schooling are characterized by a preference for literacy and numeracy to occupations of the "preschool" type (drawing, singing, physical culture, working education), a meaningful idea of preparation for school (mastering some reading, counting, writing skills), low cognitive interest, the choice of such types of encouragement as sweets, toys, an external motivation for learning (attracting beautiful school subjects and the appearance of schoolchildren), school-educational orientations in the situation of optional school attendance, a game learning motive unlike children with high motivation.

\section{Discussion and Conclusion}

The results of our study of the level of motivational readiness for school in children of senior preschool age showed that most children have average indicators of the development of motivational readiness that are not adequate for teaching children at school. In the answers of the children are dominated external, mainly evaluative motives, while at the same time, are insufficiently formed edu-cognitive and social motives. In general, we can talk about the lack of completeness of formation of the pupil's internal position.Based on the results of a stating experiment, as well as on the basis of a theoretical analysis of literary sources, we have developed a technology for the formation of motivational readiness of preschoolers to schooling. The purpose of the technology: the formation of motivational readiness for school for children of the 6th year of life, the preparation of senior preschoolers to study at school. The main forms of technology realization: educational games and exercises; educational activities; individual, group consultations; reading fiction, didactic games, didactic exercises, word 
games, games-situations. The suggested form of play and creative activity will form for children an interest in school, in children are gradually form positive ideas about the school.

The results of the analysis showed that already at the initial stage of the project on the development of motivation for cognitive activity among preschoolers, that they are interested in active joint work with teachers for discovering new aspects of the surrounding reality, they themselves form a request to solve new problems, get satisfaction from the process and the achieved result of educational activities, feel themselves successful, try to share their knowledge, skills and positive emotions with others, especially with parents. The direct involvement of parents in the educational activities actively supports their educational initiative regarding their child, as well as their desire for self-education. It follows from this, that the implementing innovative project passes successful, and the generalization of pedagogical experience and analysis of results at the final stage will find their place in the pedagogical piggy bank.

\section{REFERENCES}

1. Aliyeva S.H. (2008). Spiritual upbringing of preschool children. Baku, 160 p.

2. Javadov IA, Jafarova LK, Mammadova K.R. (2015). Features of new content of preschool education. Baku, 66 p.

3. Ibrahimov F., Huseynzadeh R. (2012). Pedagogy. In 2 volumes. Volume I - Baku: Translator 4. Aliyev R.I. Aliyeva G. (2010). Psychology Personality. Baku, 137 p.

5. Alizada A.A. (1998). Psychological problems of the modern Azerbaijan school. Baku: Ozan, $170 \mathrm{p}$

6. Ahmedov AA, Abbasov AM (2011). Conceptual problems of preschool education // Curriculum, No. 2, p.8-15

7.Bozhovich, L.I. (2012).The problem of the development of the motivational sphere of the child: the study of the motivation of the behavior of children and adolescents.M.:Academy, 289 p.

8. Zaporozhets, A.V. (2011) . Psychology. Voronezh: 230 s.

9. Tsekhanskaya, L.I. (2013). Diagnosis of the degree of mastery of some prerequisites for educational activity. M.: Academy, 123 p.

10. Elkonin, D. B. (2011). Child psychology . M.: Academy, $384 \mathrm{~s}$

11.Tuguleva G.V. (2015). Features of the psychological support of the educational process during childhood // Conference collections of the Research Center Sociosphere. \# 46. S. 62-67. 12. Creative Curriculum for Preschool, Diane Trister Dodge, Teaching Strategies 2002, 540 p. 


\section{SOBRE O AUTOR:}

\section{Aliyeva Shahla Gasim qızı}

Doctor of pedagogical sciences, Decan of the faculty of preschool education, Azerbaijan State Pedagogical University, Baku, Azerbaijan, Postal Code: AZ1000. E-mail: aliyevashaxla@mail.ru

iD http://orcid.org/0000-0002-5474-5038

Recebido em: 29 de outubro de 2019 